\title{
Effects of Fermentated Feed and Probiotic + Acidifier Supplements on Glucose Levels and Abdomen Chicken Fat Broiler
}

\author{
Askura Nikmah', Fita Ridhana ${ }^{2}$, Ilma Fitri ${ }^{3}$, Hikmah ${ }^{4}$ \\ ${ }^{1,2}$ Department of Animal Husbandry, Faculty of Agriculture, Universitas Gajah Putih, Indonesia \\ ${ }^{3,4}$ Department of Agribusiness, Faculty of Agriculture, Universitas Gajah Putih, Indonesia \\ fitaridhana12@gmail.com
}

\begin{abstract}
The purpose of this study was to determine the effect of adding probiotic acidifier on the condition of the digestive tract, glucose levels and abdominal fat in broiler chickens. This research conducted in Takengon, Central Aceh District. The parameters observed were the condition of the digestive tract, blood glucose levels and the percentage of abdominal fat. The data obtained were analyzed using analysis of variance (ANOVA). The results showed the use of a 1:1 mixture of probiotics and acidifier to level 0 . The 3\% added to the commercial ration which was substituted with $10 \%$ fermented feed ingredients $(R-K F P A)$ had no significant effect $(P<0.05)$ on weight and percentage of Gizzard, Gizzard $p H$ and Intestine $p H$, Intestinal Length, Weight and Percent of Abdominal Fat, as well as blood glucose levels in broiler chickens. Although statistically not significantly different, giving a mixture of probiotics and acidifier at the level of $0.3 \%$ $(R 4)$ showed a positive effect on decreasing the percentage of abdominal fat from $1.52 \%$ (R1) to $1.35 \%$ (R4). The blood glucose obtained in this study was slightly higher than normal blood glucose levels in chickens as reported by Swenson weight and percentage of abdominal fat, as well as blood glucose levels of broiler chickens. Although statistically not significantly different, giving a mixture of probiotics and acidifier at the level of $0.3 \%$ (R4) showed a positive effect on decreasing the percentage of abdominal fat from $1.52 \%$ (R1) to $1.35 \%(R 4)$. The blood glucose obtained in this study was slightly higher than normal blood glucose levels in chickens as reported by Swenson weight and percentage of abdominal fat, as well as blood glucose levels of broiler chickens. Although statistically not significantly different, giving a mixture of probiotics and acidifier at the level of $0.3 \%$ $(R 4)$ showed a positive effect on decreasing the percentage of abdominal fat from $1.52 \%$ (R1) to $1.35 \%$ (R4). The blood glucose obtained in this study was slightly higher than normal blood glucose levels in chickens as reported by Swenson (1993), which ranges from 13 to $27 \mathrm{ml} / \mathrm{dl}$ or 130 to $270 \mathrm{mg} / \mathrm{dl}$. It is suspected that this is due to increased digestive activity in chickens so that more nutrients are absorbed.
\end{abstract}

Keywords: probiotic acidifier; fermented feed; blood glucose; abdominal fat; broiler chickens

\section{Introduction}

In chicken farming, there are three important factors that need to be considered, namely seeds, feed, and management. Feed is the factor that requires the most costs, which is around $60-80 \%$ of all production costs. Production costs can be reduced if the efficiency of feed given to livestock increases. High feed efficiency can be achieved when the digestive tract is in optimal conditions to digest and absorb food substances. In broilers, there are several ways to optimize the efficiency of absorption of nutrients in the digestive tract. One of the methods commonly used by breeders today is by administering antibiotics. 
The use of antibiotics in livestock has a disadvantage, namely that the dosage of antibiotics must be considered because excessive use is feared to leave residues in the body of the chickens while increasing production costs. Therefore, a safer way is needed to increase the efficiency of using chicken feed which produces meat without antibiotic residue but does not kill non-pathog enic micro flora in the digestive tract and can even improve protein digestibility by utilizing an acidifier in the form of lactic acid. Acidifier aims to maintain the $\mathrm{pH}$ of the digestive tract and create a suitable $\mathrm{pH}$ condition for the digestion of food substances that enter the digestive tract and suppress pathogenic microbes and promote the growth of beneficial microbes (Hyden, 2000).

Utilization of this acidifier has been carried out in laying hens and gives good results. The use of acidifiers in broilers has been carried out by Lückstädt et al. (2004) using formic acid and propionic acid which can increase the growth of broilers under controlled conditions, namely without the use of growth-promoting antibiotics. Hyden (2000) also reported that lactic acid is one of the acidifiers that can maintain the $\mathrm{pH}$ of the digestive tract and create $\mathrm{pH}$ conditions suitable for the digestion of food substances that enter the digestive tract, suppress pathogenic microbes and promote the growth of beneficial microbes.

\subsection{Research Purposes}

This study aims to determine the effect of adding probiotic acidifier on glucose levels and abdominal fat in broiler chickens.

\section{Research Methods}

\subsection{Place and Time of Research}

Research on the effect of probiotic and acidifier supplementation in the ration on the growth and glucose levels of broiler chickens was conducted in Takengon, Aceh Tengah District. The study lasted 35 days.

\subsection{Research Material}

The material used in this study consisted of 160 broiler chickens aged one day (Day Old Chiks) cobb strain with production code CP 707, Production of PT. Pokphand, North Sumatra.

\subsection{Research Materials and Tools}

The ingredients to be used in this study consist of probiotic supplements and acidifiers, HI-PRO-VITE N511 commercial feed, fermented feed, vaccines. and vitachick. The equipment to be used includes a 1 x $1 \mathrm{~m}$ (16 units) insulated cage, a digital scale for weighing broilers, a disinfectant device. a place for drinking water and chicken feed, a bucket for storing drinking water for chickens, and a lighting lamp.

\subsection{Research Design}

The design to be used is a completely randomized design with the use of fermentation rations and a mixture of probiotic + acidifier (proaci). There are 4 treatments and each treatment is repeated 4 times. Each replication was an experimental unit consisting of 10 broilers. The treatment of using a mixture of probiotic + acidifier (proaci) supplementation and fermented feed with different levels, namely: 
A: Rations without probiotic supplementation + acidifier (control rations)

B: Rations with the use of probiotic + acidifier supplementation (1: 1 as much as $0.1 \%$ of the total ration).

C: Rations with the use of probiotic + acidifier supplementation (1: 1 as much as $0.2 \%$ of the total ration).

D: Rations with the use of probiotic + acidifier supplementation (1: 1 as much as $0.3 \%$ of the total ration).

The research mathematical model is as follows:

$Y \ddot{i j}=\mu+\alpha \ddot{i j}+\varepsilon \ddot{i j}$

Yij $=\mathrm{i}=1,2,3,4,5 \mathrm{j}=1,2,3,4$

$\mu=$ General average

$\alpha i=$ The effect of using tofu pulp flour

$\varepsilon \ddot{i j}=$ Effect of experimental error on treatment $\mathrm{i}$, group $\mathrm{j}$

\subsection{Parameters Observed}

The parameters measured in this study are:

1. Final weight; obtained by weighing the body weight of chickens aged 35 days before slaughter.

2. Analysis of blood glucose levels; calculated at the end of the study using an easy tough tool.

3. Weight and percentage of abdominal fat; obtained by weighing the weight of the fat attached to the stomach (abdomen). The percentage of abdominal fat is obtained by dividing the weight of abdominal fat by the live weight times one hundred percent.

4. Intestinal $\mathrm{pH}$; measured using a $\mathrm{pH}$ meter at the age of 35 days.

5. Gizzard $\mathrm{pH}$; measured using a $\mathrm{pH}$ meter at the age of 35 days.

6. Intestinal length; measured using a measuring tape at the age of 35 days

7. Gizzard weight and percentage; measured by weighing the gizzard. The percentage of gizzard is obtained by dividing the gizzard weight by the live weight multiplied by one hundred percent.

\subsection{Research Implementation}

This research will be carried out in several stages, namely:

1. Preparation phase

The preparation stage includes sanitizing the cage and the area around the cage, washing the cage, spraying disinfectants, making a place for feeding and drinking, and preparing the materials and compilers of treatment rations that have been milled. Each cage was given a treatment code.

2. Chickens Adaptation and Maintenance Stage

At the adaptation stage, chickens are raised starting from DOC. This stage is held as an adaptation step for livestock, before entering the data collection stage. During this stage only N511 rations are used, not mixed with fermented feed and probiotics + acidifier. Rations were given twice a day, at 07.00 WIB and 17.00 WIB. The ration was given ad libitum and the amount of ration consumption was calculated once a week. The provision of drinking water is also carried out ad libitum in the morning and evening. The drinking water and feed containers are always cleaned before adding rations or drinking water.

3. Data Retrieval Stage

Data were collected for analysis of glucose and abdominal fat levels at the age of 28 
and 35 days. Retrieval of data to determine the effect of probiotic + acidifier and fermentation rations on glucose levels and abdominal fat in broiler chickens.

\subsection{Data Analysis}

The data obtained will be analyzed by analysis of variance (ANOVA). If the ANOVA analysis shows significantly different results, it is followed by the Duncan test (Steel and Torrie, 1993).

\section{Discussion}

\subsection{Digestive Tract Conditions}

The effect of using a mixture of probiotics and 1: 1 acidifier added to the commercial ration substituted with $10 \%$ fermented feed ingredients (R-KFPA) on the digestive tract conditions of broiler chickens at 35 days of age of the four ration treatments is shown in Table 1.

Table 1.Digestive Tract Conditions of Broiler Chickens Treated With 1: 1 Probiotic and Acidifier Mixture into a Commercial Ration Substituted with $10 \%$ Fermented Feed Ingredients

Commercial rations substituted with $10 \%$ fermented

Digestive Tract feed ingredients $(\mathrm{R}-\mathrm{KF})+$ a mixture of probiotics and 1 :

Conditions

(Digestive tract 1 acidifier (PA)

condition)

$\begin{array}{cccc}0.0 \% \text { PA } & 0.1 \% \text { PA } & 0.2 \% \text { PA } & 0.3 \% \text { PA } \\ \text { (R-KF) } & (\text { R-KFPA1) } & (\mathrm{R}-\text { KFPA2) } & (\mathrm{R}-\text { KFPA3) } \\ (\mathrm{R} 1) & (\mathrm{R} 2) & (\mathrm{R} 3) & (\mathrm{R} 4)\end{array}$

Gizzard

Gizzard weight (g)

$32.25 \pm$

$31.50 \pm$

$35.38 \pm$

$34.25 \pm$

4.53

5.98

8.05

4.13

Gizzard percentage

$(\%)$

$1.69 \pm 0.21$

$1.55 \pm 0.26$

$1.74 \pm 0.38$

$1.55 \pm 0.15$

$\mathrm{pH}$ gizzard

$4.90 \pm 0.33$

$4.80 \pm 0.35$

$5.00 \pm 0.20$

$4.80 \pm 0.53$

Intestine (small

intestine)

Intestinal length $(\mathrm{cm})$

$178.38 \pm$

13.68

$182.25 \pm$

16.29

$162.13 \pm$

$177.75 \pm$

intestinal $\mathrm{pH}$

$6.76 \pm 0.22$

$6.70 \pm 0.24$

$20.05 \quad 16.16$

$6.73 \pm 0.33$

$6.73 \pm 0.35$

\subsection{Gizzard Weights}

The variance analysis showed that the use of a 1:1 probiotic and acidifier mixture into a commercial ration substituted with $10 \%$ fermented feed ingredient (R-KFPA) had no significant effect $(\mathrm{P}<0.05)$ on weight and percentage of gizzard. This shows that the use of a mixture of probiotics and acidifier (PA) does not cause gizzard weight gain. The gizzard weight of boiler chickens that received R-KFPA treatment (R2, R3, R4) in this study ranged from $31.50-35.38$ grams or $1.55-1.74 \%$ of live weight, not much different from broilers who received treatment R-KF only (R1). Broiler gizzard weights for all treatments 
in this study were even slightly lower than reported by Brake et al. (1993), namely $2 \%$ in hens and $1.8 \%$ in 5 week old male chicks. Meanwhile, Putnam (1991) stated that the gizzard weight is around $1.6-2.3 \%$ of the live weight.

\subsection{Gizzard pH}

The results of variance showed that the $\mathrm{pH}$ in the broiler gizzard in this study ranged from 4.80 to 5.0. Acidifier is used to control the $\mathrm{pH}$ in the digestive tract. If the conditions where the $\mathrm{pH}$ of the digestive tract are already optimum, the acidifier will not work to lower the $\mathrm{pH}$ because it will result in a $\mathrm{pH}$ atmosphere that is too acidic and causes digestive disorders and an imbalance of the intestinal microflora. The gizzard condition of broiler chickens that were treated with rations substituted with fermented feed ingredients ( $\mathrm{R}-\mathrm{KF}$ or $\mathrm{R} 1$ ) was optimal with a $\mathrm{pH}$ of 4.9. Acidifier no longer lowers the $\mathrm{pH}$ of the gizzard, but maintains it. In Table 1, you can see the $\mathrm{pH}$ of the gizzard of broiler chickens that received additional acidifier treatment (R-KFPA or R2, R3,

The presence of fermented feed ingredients that are substituted into the commercial ration for all treatments lighten the work of the gizzard. Fermentation helps to degrade the high fiber ingredients so that they are easier to digest. This is in accordance with the statementPurwadaria et al. (1998) and Pasaribu et al. (1998), that in the process of fermentation technology, microorganisms are needed as pengenzyme results to break down crude fiber and to increase protein levels. For this reason, broiler chickens that were treated with fermented feed ingredients (all treatments) had gizzard sizes that were not large (normal). This reinforces the notion that fermented feed, probiotics and acidifier can improve the performance of the stomach (gizzard).

\section{4 pH and Intestinal Length}

The variance analysis showed that the use of a probiotic mixture and a 1:1 acidifier into a commercial ration substituted with $10 \%$ fermented feed ingredients (R-KFPA) had no significant effect $(\mathrm{P}<0.05)$ on the intestinal length of broiler chickens. According toLindberg et al. (1982), probiotics were able to produce extracellular proteases with an acidic $\mathrm{pH}$ of 3 and a neutral $\mathrm{pH}$ of 7. Suthama and Ardiningsasi (2006) stated that increased protease activity could affect the length of the digestive tract. However, in this study, broiler chickens that received probiotic treatment (R2, R3, R4) did not show any significant effect on the length of the digestive tract. This concurs with that put forward by Sarwono et al. (2012) stated that the provision of probiotics in native chicken rations did not increase the length of the digestion channel.

The analysis of variance showed that the treatment of a 1:1 probiotic and acidifier mixture into a commercial ration substituted with $10 \%$ fermented feed ingredients (RKFPA) had no significant effect $(\mathrm{P}<0.05)$ on the intestinal $\mathrm{pH}$ of broiler chickens. Quantitatively, the data obtained in this study is almost no difference between all treatments. The $\mathrm{pH}$ value for all treatments is relatively the same, namely 6.70-6.76. The results of this study are in accordance with the statementn Natsir et al. (2006) that the combination of citric acid and lactic acid in the form of encapsulation at various levels did not have a significant effect on intestinal $\mathrm{pH}$ conditions but had a significant effect on pathogenic and non-pathogenic microbial populations.

\subsection{Abdominal Fat}

One part of the body that is used to store fat is the area around the stomach or abdomen. Abdominal fat is less useful because in the sale of carcass, this fat is removed. The effect of using a mixture of probiotics and 1: 1 acidifier added to the commercial 
ration substituted with $10 \%$ fermented feed ingredients (R-KFPA) on the abdominal and non-carcass fatty conditions of broiler chickens at 35 days of the four ration treatments is shown in Table 2.

Table 2. Broiler Chicken Abdomen Fat Treated with Probiotic and Acidifier Mix 1: 1 into a Commercial Ration Substituted with $10 \%$ Fermented Feed Ingredients

\begin{tabular}{|c|c|c|c|c|}
\hline \multirow[t]{2}{*}{$\begin{array}{l}\text { Abdomen Fat } \\
\text { (Abdominal fat) }\end{array}$} & \multicolumn{4}{|c|}{$\begin{array}{c}\text { Commercial rations substituted with } 10 \% \text { fermented } \\
\text { feed ingredients }(\mathrm{R}-\mathrm{KF})+\text { a mixture of probiotics and } \\
1: 1 \text { acidifier (PA) }\end{array}$} \\
\hline & $\begin{array}{c}0.0 \% \text { PA } \\
(\mathrm{R}-\mathrm{KF}) \\
(\mathrm{R} 1)\end{array}$ & $\begin{array}{c}0.1 \% \text { PA } \\
(\mathrm{R}-\mathrm{KFPA} 1) \\
(\mathrm{R} 2) \\
\end{array}$ & $\begin{array}{c}0.2 \% \text { PA } \\
(\mathrm{R}-\mathrm{KFPA} 2) \\
\quad(\mathrm{R} 3) \\
\end{array}$ & $\begin{array}{c}0.3 \% \text { PA } \\
(\mathrm{R}-\mathrm{KFPA} 3) \\
(\mathrm{R} 4)\end{array}$ \\
\hline Abdomen Fat Weight (g) & $\begin{array}{c}28.88 \pm \\
3.91\end{array}$ & $31.00 \pm 4.90$ & $33.25 \pm 7.80$ & $29.63 \pm 5.48$ \\
\hline $\begin{array}{l}\text { Percentage of Abdomen } \\
\text { Fat }(\%)\end{array}$ & $\begin{array}{c}1.52 \pm \\
0.22\end{array}$ & $1.53 \pm 0.24$ & $1.63 \pm 0.38$ & $1.35 \pm 0.25$ \\
\hline
\end{tabular}

The analysis of variance showed that the treatment of a 1: 1 probiotic and acidifier mixture into a commercial ration substituted with $10 \%$ fermented feed ingredients (RKFPA) had no significant effect $(\mathrm{P}<0.05)$ on weight and percentage of belly fat in broiler chickens. These results concur with Sarwono et al. (2012) who explained that the provision of probiotics in native chicken rations did not affect the weight of abdominal fat. Abdominal fat did not increase in the chickens treated with the addition of probiotics in their rations (R-KFPA or R2, R3, R4).

In general, the percentage of abdominal fat in this study is slightly higher than the study conducted by Sandi et al. (2012), the average percentage of abdominal fat weight ranges from $1.21-1.41 \%$ of live weight, but it is lower than that stated by Leeson and Summers (1980) that the percentage of abdominal fat in roosters ranges from 1.4-2, 60\% while for hens ranged from 3.2-4.8\% of body weight. Becker et al. (1981) stated that the percentage of abdominal fat in hens is higher than that of males. The same percentage of abdominal fat in the control treatment was also obtained in a study conducted by Ihsan (2006), the highest percentage of abdominal fat was in the control treatment (R0), namely amounted to $1.51 \%$ while the lowest was in the treatment of $100 \%$ silage ration (R2) which was $0.81 \%$.

Although statistically not significantly different, giving a mixture of probiotics and acidifier at the level of $0.3 \%$ (R4) showed a positive effect on decreasing the percentage of abdominal fat. This is in line with the acquisition of the final body weight of the boiler chickens at the very $\mathrm{R} 4$ treatment significantly higher than treatment $\mathrm{R} 1$. This result is in accordance with the statement of Tillman et al. (1998) that in general the increase in live weight of chickens is followed by a decrease in abdominal fat content which results in high meat production. The reduction of abdominal fat is beneficial, because it will improve the quality of carcass by producing meat that is low in fat (Sanz et al., 2000). Percentage of le the abdomen of broilers in this study is shown in Figure 1. 


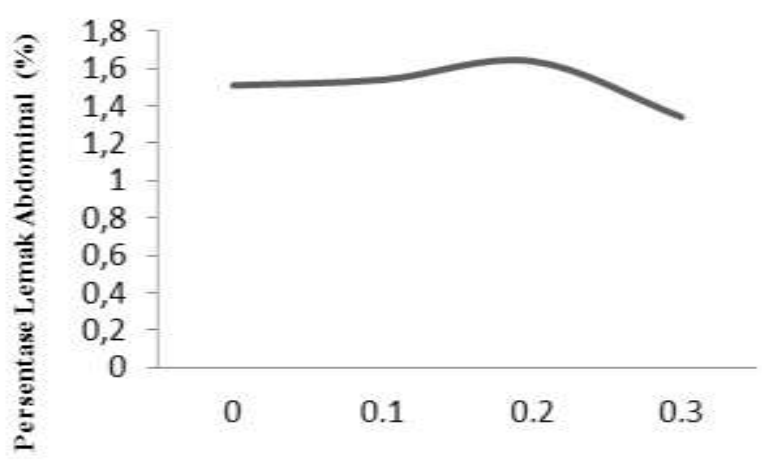

Level of Probiotic Acidifier Administration (\%)

Figure 1. Percentage of Broiler Chickens Abdominal Fat in Some Probiotic and Acidifier Mixture Level

\subsection{Glucose Levels}

Table 3. Glucose Levels of Broiler Chickens Treated with a Mixture of Probiotics and Acidifier 1: 1 into a Commercial Ration Substituted With 10\% Fermented Feed Ingredients

\begin{tabular}{|c|c|c|c|c|}
\hline \multirow[t]{2}{*}{$\begin{array}{l}\text { Glucose } \\
\text { (Glucose) }\end{array}$} & \multicolumn{4}{|c|}{$\begin{array}{c}\text { Commercial rations substituted with } 10 \% \text { fermented feed } \\
\text { ingredients }(\mathrm{R}-\mathrm{KF})+\text { a mixture of probiotics and } 1: 1 \\
\text { acidifier (PA) }\end{array}$} \\
\hline & $\begin{array}{l}0.0 \% \text { PA } \\
(\mathrm{R}-\mathrm{KF}) \\
\text { (R1) }\end{array}$ & $\begin{array}{c}0.1 \% \text { PA } \\
(\mathrm{R}-\mathrm{KFPA} 1) \\
(\mathrm{R} 2)\end{array}$ & $\begin{array}{c}0.2 \% \text { PA } \\
(\mathrm{R}-\mathrm{KFPA} 2) \\
(\mathrm{R} 3)\end{array}$ & $\begin{array}{c}0.3 \% \text { PA } \\
(\mathrm{R}-\mathrm{KFPA} 3) \\
(\mathrm{R} 4)\end{array}$ \\
\hline $\begin{array}{l}\text { Blood Glucose Level } \\
\text { (Blood glucose level) }\end{array}$ & $\begin{array}{c}290.80 \pm \\
27.10\end{array}$ & $\begin{array}{c}309.80 \pm \\
37.33\end{array}$ & $\begin{array}{c}294.40 \pm \\
35.71\end{array}$ & $\begin{array}{c}304.50 \pm \\
28.64\end{array}$ \\
\hline
\end{tabular}

The analysis of variance showed that the treatment of a mixture of probiotics and acidifier 1: 1 into a commercial ration substituted with $10 \%$ fermented feed ingredients (RKFPA) had no significant effect $(\mathrm{P}<0.05)$ on the blood glucose of broiler chickens. Chicken blood glucose for all treatments was relatively the same, namely in the range (290.75-309.75 mg / dl).

Blood glucose obtained in this study was slightly higher than normal blood glucose levels in chickens as wipedorkan by Swenson (1993), which ranges from 13 to $27 \mathrm{ml} / \mathrm{dl}$ or 130 to $270 \mathrm{mg} / \mathrm{dl}$. This is probably due to increased digestive activity in chickens so that more nutrients are absorbed. Glucose, which is the end product of carbohydrate digestion, is absorbed by the capillaries, enters the blood vessels, then to the liver to be detoxified and then carried to the heart to be circulated throughout the body. This is in accordance with the statement of Resnawati (2004), that the factors that determine blood glucose levels are the balance of glucose that enters. and out of the blood, while the factors that influence blood fluctose levels are the supply of feed, the accuracy of entering muscle and fat cells and the glucostatic activity of the liver. 


\section{Conclusion}

Based on the results of the research that has been done, the following conclusions can be drawn:

1. The use of a probiotic mixture and a 1: 1 acidifier up to a level of $0.3 \%$ which is added to the commercial ration substituted with $10 \%$ fermented feed ingredients (R-KFPA) has no significant effect on weight and percentage of Gizzard, Gizzard $\mathrm{pH}$ and Intestine $\mathrm{pH}$, Intestinal Length, weight and percentage of abdominal fat, as well as blood glucose levels of broiler chickens.

2. Although statistically not significantly different, giving a mixture of probiotics and acidifier at the level of $0.3 \%$ (R4) showed a positive effect on decreasing the percentage of abdominal fat from $1.52 \%$ (R1) to $1.35 \%$ (R4).

3. The blood glucose obtained in this study was slightly higher than normal blood glucose levels in chickens as reported by Swenson (1993), which ranges from 13 to $27 \mathrm{ml} / \mathrm{dl}$ or 130 to $270 \mathrm{mg} / \mathrm{dl}$. It is suspected that this is due to increased digestive activity in chickens so that more nutrients are absorbed.

\section{References}

Swenson, M. S. 1993. Physilogical property and chemical constituen of blood, in Dukes Physology of Domestic Animal. 9th Ed. Comstock Publising Asociates A Division of Corneil University Press. London.

Hyden, M. 2000. Protected acid additives. Feed International. July.

Lückstädt, C., N. Senöylü, H.Akyürek and A. Aĝma. 2004. Acidifier - a modern alternative for antibiotic free feeding in livestock production, with special focus on broiler production. Veterinarija Ir Zootechnika.T.27 (49).

Steel, R.G.D and J.H. Torrie. 1993. Principles and Procedures of Statistics. A Biomedical Approach. 3rd Ed. Mc Graw Hill. Kogasukha Ltd., Tokyo.

Brake, J., G. B. Havenstein, S. E. Schidelet, P. R. Ferket, and D. V. River. 1993. Relationship of sex, age and body weight to broiler carcass yield and offal production. Poultry Sci. 70: 680-688.

Putnam, P. A. 1991. Handbook of Animal Science. Academy Prees, San Diego.

Purwadaria, T., A.P. Sinurat, T. Haryati, I. Sutikno, Supriyati dan J. Darma. 1998. Korelasi antara aktivitas enzim mananase dan selulase terhadap kadar serat lumpur sawit hasil fermentasi dengan aspergillus niger. JITV 3(4): 230-236.

Pasaribu, T., A.P. Sinurat, T. Purwadaria, Supriyati dan H. Hamid. 1998. Peningkatan nilai gizi lumpur sawit melalui proses fermentasi : Pengaruh jenis kapang, suhu dan lama proses enzimatis. JITV 6(4): $233-238$.

Lindberg, R.A., W.G. Rhodes, L.D. Eirich and H. Drucker. 1982. Exracelluler acid proteases from neurospora crassa. Journal of Bacteriology 150: 1103-1108.

Suthama, N. dan S.M. Ardiningsasi. 2006. Perkembangan fungsi fisiologis saluran pencernaan ayam kedu periode starter. Jurnal Ilmiah Peternakan 9 (2): 8-20.

Sarwono, S. R., T. Yudiarti, dan E. Suprijatna. 2012. Pengaruh Pemberian Probiotik Terhadap Trigliserida Darah, Lemak Abdominal, Bobot dan Panjang Saluran Pencernaan Ayam Kampung . Animal Agriculture Journal Vol.1 (2):157-167.

Natsir, M.H, O. Sjofjan, A. Manab dan K.U. Al Awwaly. 2006. Rekayasa Produksi dan Pemanfaatan Acidifier Sebagai Aditif Pakan Unggas Melalui Teknologi Proteksi Enkapsulasi. Laporan Hasil Penelitian Hibah Bersaing XIII Perguruan Tinggi. Universitas Brawijaya. Malang. 
Sandi, S., R. Palupi, dan Amyesti. 2012. Pengaruh penambahan ampas tahu dan dedak fermentasi terhadap karkas, usus dan lemak abdomen ayam broiler. Agrinak. Vol. 02 (1):1-5.

Leeson, S. and J. D. Summers. 1980. Production and carcass characteristics of the broiler chickens. Poultry Sci. $59: 786-798$.

Becker, W. A., J. V. Spencer, L. W. Mirish and J. A. Verstrate. 1981. Abdominal and carcass fat in five body strain. Poultry Sci. 60: 693-697.

Ihsan, F.N. 2006. Persentase Bobot Karkas, Lemak Abdomen dan Organ Dalam Ayam Broiler dengan Pemberian Silase Ransum Komersial. Institut Pertanian Bogor. Bogor.

Tillman, A.D., H. Hartadi, S. Reksohadiprodjo, S. Prawirokusumo dan S. Lebdosoekojo. 1998. Ilmu Makanan Ternak Dasar. Cet. Ke-5. Gajah Mada University Press, Yogyakarta.

Sanz, S. M., A. Flores, C. J. Lopes-Bate and J.M. Carmona. 2000. Effect of the inclusion time of dietary satuted and unsaturated fat before slaughter on the accumulation and composition of abdominal fat in female broiler chiken. Puoltry Sci. 79: 1320-1325.

Resnawati H. 2004. Bobot potongan karkas dan lemak abdomen ayam ras pedaging yang diberi ransum mengandung tepung cacing tanah (Lumbricus rubellus). Di dalam: Prosiding Seminar Nasional Teknologi Peternakan dan Veteriner; Bogor, 17-18 Sep 2004. Bogor: Pusat Penelitian dan Pengembangan Peternakan. 2004. hlm 563-567. 